\title{
Business Development Services Access as a Strategic Response to Market Disruption among Small and Medium Enterprises
}

\author{
Mary Njoroge, Veronicah Kaluyu* \\ Chandaria School of Business, United States International University-Africa, Nairobi, Kenya \\ Email: mmnjoroge@yahoo.com, *vkaluyu@usiu.ac.ke
}

How to cite this paper: Njoroge, M., \& Kaluyu, V. (2020). Business Development Services Access as a Strategic Response to Market Disruption among Small and Medium Enterprises. American Journal of Industrial and Business Management, 10, 13401359.

https://doi.org/10.4236/ajibm.2020.108089

Received: July 5, 2020

Accepted: August 10, 2020

Published: August 13, 2020

Copyright $\odot 2020$ by author(s) and Scientific Research Publishing Inc. This work is licensed under the Creative Commons Attribution International License (CC BY 4.0).

http://creativecommons.org/licenses/by/4.0/

(c) $\underset{\mathrm{By}}{\text { (i) Open Access }}$

\begin{abstract}
Business development service is a pro-market and customer-centric multiple value advantage approach that is available for firms to enable them seize emergent opportunities in the market for superior customer value and sustainable competitive advantage. This paper carries out a literature review on how marketing Business Development Services (BDS) propels SMEs to strategically respond to market disruptions and pursue a sustainable competitive advantage. Its main focus is on the following four variables of marketing Business Development Services: trade fairs, trade partnerships, product development and communication with customers. Although there is limited empirical literature on study's key variables, the collected information becomes an eye opener to researchers on the need of further research using different approaches. As such, from perspectives deduced from the literature, future research orientations are prescribed. Additionally, Business practitioners and SMEs, may borrow a leaf on use of Business development services to create strong strategic postures for survival in turbulent environment.
\end{abstract}

\section{Keywords}

Business Development Services, Strategic Response, Marketing Business

Development Services Access, Market Disruption

\section{Introduction}

Small and Medium Enterprises (SMEs) are essential to many developed and developing countries. They are the central generator of economic action and the lead sector in job creation. The landscape in which SMEs operate is complex and dynamic, characterized by market disruptions due to globalization. Such a dy- 
namic business environment calls for greater efficiency and effectiveness. The survival of SMEs essentially depends on how they engage in practices that can enhance their competitiveness in the market-place (Gonçalves, Ferreira, Ferreira, \& Farinha, 2019). This requires a paradigm shift from their way of doing business to a higher arena of efficiency and superior value for their customers (Jardon, 2018). The realization of such value will highly depend on a multiple value advantage trajectory characterized by pro-market and customer-centric practices. Business development approach to revitalize SMEs also known as business development services (BDS) is one of such approaches available for growthoriented, high-appetite firms that are readily available to seize emergent opportunities in the market for superior customer value and sustainable competitive advantage (Okeyo, Gathungu, \& K’Obonyo, 2014).

The term business development services (BDS) was coined together by donor organizations in their bid to enhance the performance of SMEs in developing nations, which may in return lead to social economic growth (Committee of Donor Agencies for Small Enterprise Development, 2001; International Finance Corporation, 2006). They referred to BDS as the non-financial services and products accessible to entrepreneurs to meet their business needs and to ultimately enable them to improve their performance and competitiveness. These include: training, marketing services, technology development and transfer, access to information, business advice, consultancy and counselling services, managerial services, policy influence and administrative services. According to OECD (2018) BDS in the last decade has evolved rapidly. The report documents the proceedings of an international conference which was organized by the Organisation for Economic Co-operation and Development (OECD) in the United Kingdom. It asserts that BDS promote growth, innovation, exports and capacity for knowledge absorption by SMEs. Therefore, BDS may trigger SMEs' productivity growth and exploit emerging digital technological opportunities.

Okundaye, Fan, \& Dwyer (2019) observe that small and medium enterprises (SMEs) globally, have played an important role in economic development, poverty reduction and job creation. The authors argue that SMEs are imperative to economic growth of many countries. Gray \& Jones (2016) posits that in the European Union (EU) economy, SME sector is vital, employing over 87 million people. In the United States (US), SMEs are the pillar of the economy, contributing significantly to the economic growth. The total population of about 28 million SMEs provides almost two-thirds of the employment in the Nation (Global Entrepreneurship Monitor, 2019). In Malaysia, support to SME sector has resulted to significant growth of the sector (Government of Malaysia, 2016). Rambe \& Mosweunyane (2017) posit that the South African government regards entrepreneurship as one of the vital pillars for addressing poverty and unemployment. In developing countries, $80 \%$ of the jobs are created by SMEs. These countries need high growth-oriented SMEs that can sustain steady growth and respond promptly to market disruptions to function at a superior performance level 
(United Nations Secretary General, 2014). In Ghana, SMEs constitute almost $90 \%$ of businesses and account for about $80 \%$ of total employment (Quaye \& Mensah, 2018). SMEs in Nigeria contribute to $90 \%$ of the total national enterprises (Okundaye, Fan, \& Dwyer, 2019). Kenyan SMEs offer the highest job creation opportunities, totaling 14.9 million employees, plays a vital role in wealth creation and is a source of income for thousands of Kenyans (Kenya National Bureau of Statistics, 2016).

Business Development Services is construed as a strategic response to small and medium enterprises (SMEs) that is crucial in addressing business challenges such as disruptions in the market, swift growth and survival challenges. Globally, business development services (BDS) access options for developing of SMEs have been increasing. They are key enablers of improved business management, are drivers of employment creation and enhances accessibility of financial services by the SMEs (International Finance Corporation, 2006). Accessing BDS such as business technological hubs and incubators have been enabled to boost the creation of growth oriented SMEs (United Nations Secretary General, 2014). In the UK for example, there are a range of business development services and enterprise programmes initiated for access by SMEs to assist start ups and entrepreneurs towards success. In the United States, accessing BDS such as advanced commercial, legal and physical infrastructure has promoted an entrepreneurial culture enabling SMEs to thrive (Global Entrepreneurship Monitor, 2019). In Malaysia, the Government has come up with BDS access initiatives for SMEs with adequate budgetary allocations. These initiatives are implemented in collaboration with private sector, which play a pertinent role in provision of BDS (Ombi, Ambad, \& Bujang, 2018). Ongoncho, Ngugi, Odhiambo, \& Kamaara (2017) in a study conducted in Kisii County in Kenya, assert that access to BDS improves the performance of SMEs.

While the above studies show a positive correlation between access to business development services (BDS) and performance of SMEs, including responsiveness to market disruptions, other studies have revealed a divergent view. Gray \& Jones (2016) posit that despite the important role SMEs play and strategically availing BDS to them, their business performance has not met expectations in terms of economic growth and development. In the European Union Economy, for instance, they have not contributed significantly to a decrease in poverty levels. A similar observation is noted for SMEs in Malaysia, where there is a high growth of the number of SMEs, but poverty levels are rising. This demonstrates the limited production efficiency of SMEs and their low capacity to convert economic opportunities into robust life-sustaining capabilities (Government of Malaysia, 2016). Meru \& Struwig (2015) conducted a study on business incubators in Kenya. The study recommended that access to marketing BDS should be improved to make marketing easier in the country.

The dichotomy regarding how accessing business development services (BDS) by SMEs affect their performance, provides an opportunity for further research 
in this area of knowledge. This paper contributes to this gap by examining if BDS access is a strategic response to market disruption among SMEs in Kenya. The research takes an analytical approach to demonstrate how access to BDS propels SMEs to strategically respond to market disruptions and pursue a sustainable competitive advantage. The paper has reviewed different researches conducted globally, regionally and nationally on the accessibility of marketing BDS by SMEs and how this enable them to strategically respond to the market disruptive environment, while at the same time pursuing a sustainable competitive advantage. The research will focus on marketing BDS and will examine the following four sub-variables: Trade fairs, trade partnerships, product development and communication with customers.

\section{Significance of This Study}

The significance of this cannot be underestimated; it will indeed be useful to different constituents including SMEs, policy makers, business development services providers, researchers and academicians. SMEs operate in a business environment that is faced with disruptions and because of business to business interdependence in the supply and value chains, these dynamics may trigger adverse effects on individual business. This study is an enabler to SMEs' responsiveness to market disruptions as it provides knowledge on the strategic role access to marketing business development services play in enhancing their resilience to these shocks. The research will enable policy makers to focus on evidence-based policies for cushioning business from adverse effects of disruptions. BDS providers may refer to this paper in their design for BDS support programmes and researchers and academicians will have access to additional information in the body of knowledge on SMEs.

\section{Methodology}

This paper investigated if accessibility of marketing BDS by SMEs provides a strategic response to market disruptions. The study applied an analytical approach of the existing literature. According to Andrews, Higgins, Andrews, \& Lalor (2012) there exists a lot of secondary data that has been collected and archived by researchers globally and researchers can use this secondary data for their researches. Smith (2008) affirms that use of secondary data is cost effective and convenient, hence when available, researchers can utilize them for high quality researches. The authors of this paper reviewed articles from research conducted globally, regionally and nationally on access to marketing BDS by SMEs. An initial review was conducted that led to the emergence of four marketing BDS themes: trade fairs, trade partnerships, product development and communication with customers. The authors used these themes to sharpen the specific objectives of the study. The second stage entailed a review of research conducted on the four themes. To allow a balanced review under each theme, the authors adopted a global, regional and national approach focusing on the re- 
levance to the overall research objective of how access to marketing BDS is a strategic posture or not for SMEs for market disruptions. The findings from the reviewed studies, enabled the authors to establish how access to marketing BDS enables SMEs to withstand the volatile disruptions in the market place, thus enhancing their survival.

Subsequent, is an in-depth literature review on how access to the four sub-variables of marketing BDS by SMEs is a strategic posture for their response to market disruptions. Based on the reviewed literature, findings of the study are discussed. This is followed by the conclusion on how access to marketing BDS ringfences SMEs against the adverse effects of market turbulences, the limitations of the study and suggestions for future research. The paper then provides a recommendation pointing to the effectiveness of BDS access as a survival strategy for SMEs during volatile times, hence its importance to global business community especially SMEs.

\section{Research Objectives}

Main Objective of this research was to carry out systematic literature review on marketing business development services access as a strategic response to market disruption among Small and Medium Enterprises.

The study focused on the following four specific objectives:

1) To analyze trade fairs access as a strategic response to market disruption among SMEs in Kenya.

2) To expound on trade partnerships access as a strategic response to market disruption among SMEs.

3) To explore product development as a strategic response to market disruption among SMEs.

4) To analyze communication with customers as a strategic response to market disruption among SMEs.

\section{Literature Review and Analysis}

Existing literature was reviewed based on the various study objectives:

\subsection{Trade Fairs Access as a Strategic Response to Market Disruption among SMEs}

Trade fairs are a core element of marketing business development services (BDS). Trade fairs are defined as single location events that gather a cluster of suppliers in a single site, to set up physical displays of their products and services. They are also referred to as trade shows or exhibitions and can be international, national or local events. They can be either horizontal or vertical. Vertical trade fairs are where goods or services from one industry are exhibited while horizontal trade fairs is where assorted products and services from diverse industries are exhibited (Black, 1986; O’Hara, 1993; Measson \& Campbell-Hunt, 2015). Businesses attend trade fairs for several reasons such as, promotion, access to infor- 
mation and knowledge acquisition and for networking. Trade fairs are viewed as enabling platforms for making huge sales and thus may strategically position businesses' responsiveness to market disruptions. Although actual sales may not necessarily occur on the exhibition display, they highly influence purchasing decisions in the subsequent period up to two years, thus can sustain firms through turbulences in the market. Trade fairs also provide an opportunity for businesses to showcase or promote their products (Measson \& Campbell-Hunt, 2015). Trade fairs are also a networking platform since they enable businesses to interact with each other, thus initiating and enhancing network infrastructures. Such networking opportunities may offer small and medium enterprises (SMEs) the opportunity to grow and expand their activity overseas, thus enabling a strategic posture for efficient response to market disruptions.

Organisations may also participate in trade fairs to acquire information about their products and to enhance their knowledge on current industry trend. Such information is useful for growth into new product offering and about emergent technologies in the industry. This information enables businesses accumulate vital knowledge about the market which they may tap during market disruptions to steer the business through successfully (Gebarowski \& Wiażewicz, 2014; Maskell, 2014). Information collected at trade fairs tend to be vital to long-term decision-making process and often enable businesses such as SMEs to be strategically prepared for market turbulences.

Measson \& Campbell-Hunt (2015) conducted a study in New Zealand to examine how SMEs' participation in trade fairs enable establishment of network relationships within a global value chain. The research used literature review and case analysis. A purposive sampling was applied to select a sample of six SMEs for the study. The study examined if firms participate in trade fairs for selling, networking, information gathering or promotion. The study findings show that all the six SMEs considered: selling as a principal goal for their attendance at trade fairs; access to information and gaining market knowledge as a key motivation for their participation; promotion as a valuable determinant for attending trade fairs. Four SMEs participated in trade fairs to enlarge their network while two did not aim to enlarge their network but rather to sustain their current networks. The study overall findings established that international trade fairs provide great opportunities for network-building possibilities for SMEs and they are also instrumental in sustaining these partnerships. Trade fairs therefore are an important marketing aspect of these SMEs for their sustainability especially sustaining sales during market disruptions.

Gębarowski \& Wiażewicz (2014) conducted a study among exhibitors of the 2013 Trade Fair of Regions and Tourist Products TOUR SALON. TOUR SALON is the biggest exhibiting fair of the tourism sector in Central and Eastern Europe. The research was conducted to establish the reasons why exhibitors participate in trade fairs and whether they provided a platform for knowledge sharing about the tourism industry. The 2013 edition of the TOUR SALON hosted more than 
600 exhibitors from 39 countries and the fair attracted more than 18,000 visitors (Gębarowski \& Wiażewicz, 2014). The findings of the study confirmed that the exhibitors participated in the fair to gain market information on latest trends in the tourism industry and learn the behavior and offering of their competitors. Sharing knowledge about tourism products was also important and the opportunity to learn customers' demands and expectations. The respondents confirmed that the fairs are important in the overall marketing of their organizations. These factors are vital in strengthening the strategic posture of the businesses in the market place, giving them an edge in their responsive behaviour towards market disruptions.

A study of women in small and medium entrepreneurs in Tanzania by Nyamagere \& Nchimbi (2018) reveal that they have benefited from participating in trade fairs organized by different business development services (BDS) providers. The trade fairs have exposed them to new ideas and enhanced their creativity, which has enabled them to increase the sales of their products. The study focused on 8 entrepreneurs out of which 4 indicated that they connected with most of their large customers during trade fairs. The SMEs indicated that trade fairs also create learning platforms because the entrepreneurs learn from one another especially concerning the product quality improvement. The entrepreneurs however lamented that the long duration of the fairs (7 to 10 days) is costly due to time out of their business and being away from their families and travelling costs.

Another study was conducted in Zimbabwe during the World Tourism Expo 2017, an event that took place in Zimbabwe International Trade Fair (ZITF) grounds in Bulawayo (Shereni, Mpofu, \& Ngwenya, 2018). The research purposively sampled 60 respondents from a population of 340 exhibitors who attended the event. The Expo is a premier event in the hospitality and tourism business calendar and it hosts small and medium enterprises (SMEs) along with large firms. 93\% of the exhibitors were from Zimbabwe while the other 7\% were from other African countries including South Africa, Mozambique, Ghana, Malawi, Zambia and Egypt. The study findings reveal that the Expo facilitates interaction with customers and other actors in their industry (networking), enables firms to generate new business, provides insight about current industry trends and competitors' behaviour as well as interaction with policy makers (access to information). The findings of the above studies are in agreement with Maskell (2014) assertion that organisations use trade fairs to obtain information, acquire entry into new markets, better understand the current industry trend, expand their product offering and to know the current technologies in the industry.

According to Mwitari (2018) Kenya's SMEs' have utilized overseas trade shows to gain entry into overseas export markets. Trade shows are considered as the fastest route by SMEs to get their brands into the market and to meet potential buyers. The Kenya Export Promotion Council (EPC) in 2015 supported SMEs to gain entry into export market by sponsoring them to international ex- 
pos, exhibitions and trade fairs. These SMEs have formed a trade fair association named Ubunifu Association Kenya, which supports SMEs to get entry into international markets. In 2018 the 50 SMEs under the Ubunifu umbrella made sales of more than Kshs1 million. Members report being able to increase their sales through local and international markets. This diversification and entry into global markets has strategically positioned SMEs to better respond to market disruptions and mitigate risks of business failure and closure associated with SMEs.

Malaika Gifts \& Interiors is a small enterprise that was started in 2015 by Kamaldeep Sandhu. Back then the Kenya Export Promotion Council was supporting local manufacturers to attend international trade fairs. Since then the company has brought together about 30 artists who produce quality products for local and export markets. EPC opportunities opened an opportunity to penetrate the external market. The company adopted a dualistic approach of trade fairs and trade partnerships with other artisans, enabling the company to offer diversified products in the market while at the same time enabling other small artisans' companies to grow. The partnership has also enabled the company to make the right choices of products for different export destinations since markets are different in customer demands and standards (Mwitari, 2018).

\subsection{Trade Partnerships Access as a Strategic Response to Market Disruption among SMEs}

Business development services (BDS) place a vital role in trade partnerships. Puthusserry, Khan, \& Rodgers (2018) defines trade partnerships as non-equity collaboration modes such as exporting or sourcing. A trade partner is a business person or organization with whom somebody does business. Entrepreneurs may develop trade partnerships to enter each other's markets for mutual benefit. A socialization strategy such as networking events and trade conferences are pathways to identifying and linking with a potential trade partner. Such partnerships may open opportunities such as access to foreign markets especially for entrepreneurs lacking prior international experience or network.

Trade partnerships also, actively promote linkages between corporate sector and SMEs sector. BDS also encourage commercial sponsorship for marketing events and assists in networking with umbrella organizations and non governmental organizations working with small and medium enterprise (SMEs). These business linkages broaden their support system and boost lobbying actions that are necessary for sustainable businesses (Nyamagere \& Nchimbi, 2018). The presence of SMEs in a country encourages trade partnerships because it allows large enterprises to outsource part of their activities to smaller firms thus growing business opportunities and enhancing the overall economic development (Harris \& Patten, 2014). Fararah, Al-Swidi, \& Yusoff (2014) states that promoting and sustaining trade partnerships is a key business development services (BDS) function and upcoming small businesses can immensely enhance their 
chances for survival and growth by forming trade partnerships with large and established firms. Local SMEs can offer large international firms with opportunities to reduce costs and enhance flexibility and specialization, in areas such as procurement, distribution and sales. Trade partnerships also promote local integration, enables access to local knowledge and enhances growth of the local SMEs (Jenkins, Akhalkatsi, Roberts, \& Gardiner, 2007). Thus, trade partnerships are critical for SMEs because such cooperation provides a strategic posture for the SMEs to weather through turbulences that may otherwise disrupt their existence and survival.

Galilee International Management Institute (2017) states that governments may enter into trade partnerships with small and medium enterprises (SMEs). However, most often governments do not do enough to facilitate the partnership arrangements. Government tenders, for example, require financial resources which are unrealistic for SMEs. Additionally, the SMEs that supply goods or services to governments often experience delays in payments, which is disastrous and may cause inevitable business closure. Governments may provide subsidized training to increase SMEs' productivity and ease their employees' capacity building costs. Such training however, may encounter hiccup in the identification of the correct SMEs for the training. This study therefore does not support trade partnership between SMEs and the public sector as a strategic posture for SMEs' survival during disruptive market conditions.

Kraus, Klimas, Gast, \& Stephan (2019) conducted a research among 18 SMEs operating in the German-speaking countries of Europe to examine if trade partnerships existed among competing small and medium-sized breweries. The study refers to such partnerships as coopetition, which is a partnership between two or more competitors that allows both competition and cooperation with each other. Some of the benefits cited about coopetition trade partnerships include: higher levels of performance, competitiveness and innovation (Estrada, Faems, \& De Faria, 2016); and commercialisation of individual products under a regional umbrella brand, enabling coopetitors to have a bigger market impact compared to individual, non-coopeting actions brand (Granata, Geraudel, Gundolf, Gast, \& Marques, 2016). The findings of the study indicate that SME craft brewers coopetitors enter into trade partnerships to create synergies in product quality, production processes, costs, sales, marketing activities and mutual assistance. Such trade partnerships are anchored on trust, commitment and mutual benefit. Sympathy towards each other and towards the products was also found to be a vital element of cooperation between competing craft breweries SMEs. The findings align with those of (Gast, Kallmuenzer, Kraus, Gundolf, \& Arnold, 2017) that coopetition among SME coopetitors grow strong, long-term partnerships, which sometimes translate into close friendships. The study thus reveals that when competitors come together to cooperate for mutual benefit, such business partnerships provide a strategic posture for members of the partnership to better respond to market disruptions. 
TradeMark East Africa (2018) states that TradeMark East Africa (TMEA) is facilitating trade partnerships through One Stop Border Posts (OSBPs). Transportation for products to market destinations enhances market access and it is an element of the cost of the products. Due to the high transportation costs in the East African region, the cost of products is relatively higher and less competitive for international markets. OSBPs aim to reduce business transit costs in the cross-border trade partnerships. OSBPs addresses efficiency in the time goodstransporting trucks and people take at border points by providing infrastructural facilities to simplify processes and procedures. The findings of the study reveal that the time taken to clear goods at the Taveta Kenya-Tanzania border post has considerably reduced by about $76 \%$, from about three weeks to three days, while clearance of individuals has reduced from two hours to five minutes. By enhancing efficiency and thus reducing transportation cost, businesses including SMEs improve their revenue and profits enabling them to better respond to market disruptions.

Nyamagere \& Nchimbi (2018) shares case studies of 8 entrepreneurs in Tanzania who accessed business development services. They authors argue that women entrepreneurs were missing business opportunities due to lack of relevant information as channels for providing marketing information to women entrepreneurs were limited. They cited an example of an entrepreneur who packs delicious and nice sardines in Mwanza town and sells them to passersby at low prices. One time she found her sardines being sold outside Mwanza at four times her selling price. Accessing business development services (BDS) provided trading partnerships to supply sardines to big shops, enabling her to generate more revenue. She later established her own stall where she was able to sell the sardines in the tourist market. The findings of the study reveal that, BDS facilitated collaborative marketing where the women entrepreneurs established trading relationship between; small and large enterprises and rural and urban firms. BDS also enabled the entrepreneurs to reach many customers, establish partnerships with suppliers and wholesalers and improve the quality of their products and services. This, enhanced their space in the market place thus increasing their income and contributing to the growth of their businesses. The study therefore clearly shows that the trade partnerships established between the women SMEs and other market actors, enhanced their business growth and stabilized their businesses to better respond to market disruptions.

Diochon \& Ghore (2016) undertook a programme review in Kenya of a trade partnership initiative "Farm Shop" which was conceived in 2012 to strategically respond to the lack of infrastructure for agribusiness SMEs in Kenya. The programme was piloted in Kiambu County, Kenya, to facilitate improvement of productivity among agricultural SMEs (producers) through improved accessibility of inputs. Prior to the initiative, inputs were mainly sold by informal agrodealers, with poorly stocked shops and poor customer relations. The SME Agriproducers had no varieties to choose from and thus had to buy whatever was 
available. The agro-dealers (shop owners) lacked adequate capacity to transfer required knowledge or offer advisory services to the SME Agri-producers. The initiative facilitated access to high quality seeds, chemicals, fertilizers, animal feed, medicines to the SME Agri-producers in a timely manner and at affordable prices. Advisory services were also made available. The trade partnership added value along the value chain by enhancing the capacity of agro-dealers to offer quality goods and services to SMEs they were serving and to complement this with advisory services. The agro-dealers reported immense business growth, breaking even at a sales level of 150,000 Ksh within three to four months. Ten fully operational shops were established serving about 4000 households. The business partnership has empowered the stockist and the SME Agri-producers can get high quality inputs and advise leading to increased production and income and ultimately a better quality of life. This trade partnership has thus strategically positioned both the SME Agro-dealers and SMEs Agri-producers to better respond to market disruptions through improved efficiency and incomes.

Twiga Foods was established in Kenya in 2014, to build a unique end-to-end distribution network for fresh and processed food. The Company has established partnerships with over 17,000 SME agri-business producers and over 8000 retailers. The partnership is anchored on a digital platform and logistics network for SMEs that links retailers with farmers and food manufacturers, offering a convenient and reliable alternative to the inefficient and expensive farm/factoryto-market arrangements. Twiga model is a mobile-based, cashless platform that aggregates urban retail demand, enabling thousands of SME vendors access to one-stop shop ordering. Retailers access cheaper, higher-quality fresh produce and processed food which is conveniently and reliably delivered to their premises within 18 hours of ordering. The Agri-producers and food manufacturers have access to a fairly priced, transparent market. Twiga uses mobile money to pay agri-producers within 48 hours after collection of their produce, providing them with greater income visibility and enabling better financial planning (Ngugi, 2019). The trade partnership has provided a strategic posture for agri-business SME retailers, manufacturers and producers to respond to market disruptions.

\subsection{Product Development as a Strategic Response to Market Disruption among SMEs}

Small and Medium Enterprises (SMEs) in both developed and developing countries are facing challenges of building product quality, cost and technology. They are increasingly compelled to improve reliability of machines to improve their performance standards and quality of product in order to effectively compete in global market (Jain, Bhatti, \& Singh, 2015). Product advantage is identified as a critical product attribute in explaining the success of a new product. The quest for SMEs to improve new product performance is central in supporting their survival and growth. They face increased competition, reducing product life cycles, product imitations and high need to constant change products. Hence, 
building product advantages into their new products to increase product adoption is a key quest for SMEs (Healy, O'Dwyer, \& Ledwith, 2018).

Product development embraces packaging since it is a powerful promotional tool and the customer perceives a product through silent communication facilitated by the packaging (Gofman, Moskowitz, \& Mets 2010; Zekiri \& Hasani, 2015; Jerzyk, 2016). Packaging is part of the product as it enables distribution of contents to the customer or end-user in the right condition. It protects the packed contents from damaging elements such as, moisture, heat, light penetration, vibration, pest and leakage and also differentiates goods enhancing attraction to customers. Packaging highly influences customers' decisions because it is the first thing that a consumer sees, hence is a major element of the project design (Min, Idris, \& Yusoff, 2018).

Liu, Ko, Ngugi, \& Takeda (2017) undertook a study among small and medium enterprises (SMEs) in the United Kingdom to establish how SMEs improve their performance through new product development (NPD) performance. The authors defined NPD performance as the extent of financial and market performance success of a new product. Data were collected from a cross-sectional questionnaire survey of 401 SMEs in the manufacturing sector. The study established that new product development was driven by innovative capability and has a positive correlation with SMEs' performance.

According to Quaye \& Mensah (2018) new product designs and packages are key drivers of sustainable market advantage. They conducted a study among 591 SMEs small and medium enterprises (SMEs) in Ghana. The SMEs were randomly selected from a population of 7832 manufacturing SMEs. The study findings established that product design is a major contributory to sustainable market advantage and Ghanaian manufacturing SMEs are driven by product design innovation. By having a sustainable market advantage, they are better equipped to respond to market disruptions.

Yaseen, Bryceson, \& Mungai (2018) conducted a study to investigate the impact of market orientation on the commercialization behavior among 272 SMEs Agri-producers in Kenya. A key element in SMEs Agri-producers is product development which results from training programs, covering new production methods, input selections, value addition and commercialization. Such product development emanates from innovation and value addition which is driven by market needs. Thus, through product improvement or development, the SMEs Agri-producer make the right production and marketing decisions in responding to the target market needs. They seek and respond to market information on continuing basis, enhancing their ability to continually understand the changing market needs. This enables them to raise their awareness on how to better respond to these needs including during market disruptions.

M-Kopa Solar, is a power company selling solar power systems to the poor in Kenya. M-Kopa Solar offers a new product that provides affordable, clean, renewable power to millions of off-grid households. M-Kopa power system costs 
\$200 and contains a solar panel, an LED flashlight, two LED bulbs, adaptors for charging a phone and a rechargeable radio. It comes with a two-year warranty, with a lifespan of at least four years. The innovation has both the physical product and the strategy developed to make it affordable, which is coined with the name Kopa, which means "to borrow" in Swahili. The consumers pay \$35 upfront and are advanced a loan of $165 \$$ which is recovered through a daily payment of 45 cents for a year. As an SME, M-Kopa Solar has demonstrated that product development can provide strategic positioning for a company in the market place and also create a sustainable competitive advantage (Faris, 2015). Its solar system is beneficial to the environment, its customers and makes money for the proprietors, a real strategic posture to respond to market disruptions.

\subsection{Communication with Customers as a Strategic Response to Market Disruption among SMEs}

Market orientation requires the application of different information from different units in a business to exhaustively respond to customers needs. Hence market-focused businesses aim to understand their customers better and use customer information to create superior customer value. Thus communication with customers is vital for business performance (Matanda \& Ndubisi, 2009). Communication with customers also enables coordination and communication between business functions which ultimately help to create market conditions to successfully create superior value for the customers. Customers tend to categorize an organization as caring if it is effectively and promptly responsive to their enquiries or complaints. Consequently, customers willingly assist in giving positive and constructive feedback. This kind of engagement results to strengthened customer loyalty and the increment of new customers. Thus, the communication between a firm and its customers is a profitable resource since the company is able to gain competitive advantages. Such advantages are generated by demonstrating proper care and affection for the customers and in making them part of the value creation process (Hassan, Haniba, \& Ahmad, 2019).

Yanes-Estévez, García-Pérez, \& Oreja-Rodríguez (2019) conducted a study in Canary Islands, Spain to analyse the information shared by small and medium enterprises (SMEs) with their customers and suppliers and the implications of this interaction on their performance. The findings of the study show that most SMEs share information regularly with both customers and suppliers. The study established that these SMEs that share information regularly with customers perform better than their competitors who do not share. Sharing of information by SMEs with their customers about their business for example, inventory levels, product improvement, development of new products or sales promotion strategies enables fact-based and customer-focused decision making (Galvão, Carvalho, Oliveira, \& Medeiros, 2018). This promotes cooperative in the supply chain, which may enhance better positioning in the market place as firms' better respond to the changing demands and specific needs of the customers. This also 
gives the SMEs a strategic position to better respond to the fast-changing customer needs and expectations.

Ledikwe, Roberts-Lombard, \& Klopper (2019) undertook a study to investigate the extent to which the attitudinal loyalty of customers of small and medium businesses in apparel industry is influenced by their perceptions of commitment, trust and satisfaction. A quantitative descriptive research approach was employed on three selected small and medium enterprise (SME) brands in Gaborone, Botswana. Questionnaires were distributed out of which 260 responses from customers were suitable for data analysis. The study findings reveal that customers' trust, commitment and satisfaction have a positive and significant influence on their loyalty, which ultimately influence their behaviour towards a brand. Thus, for SMEs should cultivate commitment, trust and satisfaction of their customers to grow their sales and market positing, giving them an edge to respond to the market volatility.

Matanda \& Ndubisi (2009) conducted a study on agribusiness small and medium enterprises (horticultural producers) in Zimbabwe to establish if their market posture leads to the creation of superior customer value and organisational performance. 450 agribusinesses SMEs were selected through random sampling from a population of 2500 agribusinesses involved in the production of commercial horticultural fresh produce in Shona speaking districts in Zimbabwe. The study findings indicate that market-focused businesses viewed customer value creation as the capability to offer the required product and quality, at a satisfactory price and high reliability to deliver as strategic in delivering superior value to the customers in the fresh produce industry. The findings indicate that businesses that were customer focused were more responsive to customer needs thus, created better value for customers, which in return gave them a strategic posture to respond to market disruptions.

Irungu \& Arasa (2017) undertook a study to assess the factors influencing organizational competitiveness among the Small and Medium Enterprises (SMEs) in Kenya. A sample size of 25 SMEs was selected through stratified random sampling from a population of top 100 SMEs in Nairobi County. The study results indicated that strategic leadership influenced organizational competitiveness and attainment of a sustainable competitive advantage of the firm. Such leadership provides inspiration and motivation for the employees to perform better, including shaping the way they engage and communicate with customers. Focusing on developing the human resources, SMEs promote their organizational capabilities and value in the market place with a profound focus on customer needs and expectations. This also enhances capacity for market intelligence to meet the best standards and be in constant engagement with their customers to better understand and respond to their fast-changing requirements. This enables them to embrace various competitive strategies to remain relevant in the market even during turbulences.

Safaricom Limited, one of Kenya's blue-chip companies has adopted a strong 
customer relationship management practices that involves a one-on-one communication with the customers. The company invests heavily in employee capacity enhancement in customer service management skills including, listening to customer problems and timely response to their problems. Safaricom continually engage its customers for feedback on issues and provides almost instant feedback. Customer follow-ups are made through phone calls to confirm they are satisfied with the services provided by the company's Customer Care Centres. This direct communication with customers enables timely response to their problems. Through the creation of a rapid customer response framework, Safaricom has remained a leader in the mobile phone communication landscape, thus giving it a strategic posture for responding to market disruptions and to sustainably maintain its competitive advantage (Gitonga, 2016). While Safaricom is a large firm, it has a network of numerous SMEs such as dealers and Mpesa operates, which are part of the business success case of Safaricom.

\section{Summary of Findings}

The literature analysis and business practices discussed in this paper show that marketing business development services (BDS) access is a strategic response to Market Disruption among SMEs globally. The paper further highlights studies among SMEs in Kenya that have accessed BDS, which has enabled them to create a strategic posture, propelling them to respond effectively to market disruptions. SMEs consider trade fairs as opportunities for enhancing their sales, promoting their products and services, networking, access to information about new technology, competitor's products and innovations, and for learning and acquisition of knowledge. Trade partnerships among SMEs and between SMEs and large firms are strategic frameworks for growth and survival, positioning SMEs to better respond to market turbulences. Trade partnerships between SMEs and the government was however not found to be a strategic collaboration for business survival and responsiveness to market disruptions. Product development including packaging is used by SMEs to create superior value for customers by offering products that meet their expectations regarding tastes, quality and prices. To effectively respond to changing customer tastes and demands, SMEs constantly improve the existing products or develop new ones. Communication with customers is the propeller for SMEs' competitiveness. It provides SMEs with information about customer needs and tastes, enables interaction with customers, thus creating trust and brand loyalty. This gives the SMEs a strategic posture to respond to market disruptions.

\section{Conclusion}

SMEs operate in a turbulent environment due to globalization such that if adverse factors affect business in one part of the globe, this may trigger market disruptions in a different location. The reviewed literature in this paper indicated that by accessing business development services (BDS), SMEs may strateg- 
ically ring fence themselves against the adverse effects of market turbulences. Accessing marketing BDS enable SMEs to strategically generate mitigation measures which strengthen their positioning in the market place and improve performance. This promotes their ability to respond to many business challenges including market disruptions. In consideration of the central role played by SMEs in national development and job creation, governments should strengthen the policy mechanisms for their accessing BDS.

\section{Limitations}

The study is based on secondary data that has been conducted by other authors in different parts of the World. As noted by the Oxbridge Research Group (2020), secondary data may not ascertain absence of biases in data collection process of the reviewed literature. Secondly, business environment is dynamic due to globalization and other factors hence findings of a research in a given time may change, thus giving primary data an advantage. However, very useful insights for practice and further research are deduced.

\section{Recommendation}

This study is a pointer to the undisputable potential of SMEs BDS access in fostering business survival in a volatile market environment. Future research in this diverse area is necessary since businesses including SMEs operate in a global market that is highly characterised by disruptions. Hence further research in this area would provide useful knowledge to the business community especially SMEs on how they can strategically position themselves for timely and effective response to market disruptions. Such a strategic posture is vital for their growth and survival in the turbulent environment in which they operate. In light of these arguments, the authors point to need for further research to investigate the research objectives using primary data, quantitative and statistical methods of analysis as well as use of structural equation modelling to establish causal relationships in specific business contexts.

\section{Conflicts of Interest}

The authors declare no conflicts of interest regarding the publication of this paper.

\section{References}

Andrews, L., Higgins, A., Andrews, M. W., \& Lalor, J. G. (2012). Classic Grounded Theory to Analyze Secondary Data: Reality and Reflections. The Grounded Theory Review, $11,12-26$.

Black, R. (1986). The Trade Show Industry: Management and Marketing Career Opportunities. East Orleans, MA: Trade Show Bureau.

Committee of Donor Agencies for Small Enterprise Development (2001). Business Development Services for Small Enterprises: Guiding Principles for Donor Intervention. Washington DC. 
Diochon, M. C., \& Ghore, Y. (2016). Last Mile Farm Inputs: Farm Shop Delivers. Emerald Emerging Marketing Case Studies, 6, 1-22. https://doi.org/10.1108/EEMCS-03-2016-0025

Estrada, I., Faems, D., \& De Faria, P. (2016). Coopetition and Product Innovation Performance: The Role of Internal Knowledge Sharing Mechanisms and Formal Knowledge Protection Mechanisms. Industrial Marketing Management, 53, 56-65. https://doi.org/10.1016/j.indmarman.2015.11.013

Fararah, F. S., Al-Swidi, A. K., \& Yusoff, W. S. W. (2014). Business Development Services Provided by Islamic Microfinance Institutions and Customer Satisfaction: The Mediation Role of Perceived Benefits. A Study on SMEs in Yemen. Journal of Entrepreneurship and Business Innovation, 1, 60-78. https://doi.org/10.5296/jebi.v1i1.6111

Faris, S. (2015). The Solar Company Making a Profit on Poor Africans. https://www.bloomberg.com/features/2015-mkopa-solar-in-africa

Galilee International Management Institute (2017). How Governments Can Support SMEs. https://www.galilcol.ac.il/Spotlight/5943/How_Governments_Can_Support_SMEs

Galvão, M. B., Carvalho, R. C., Oliveira, L. A. B., \& Medeiros, D. D. (2018). Customer Loyalty Approach Based on CRM for SMEs. Journal of Business \& Industrial Marketing, 33, 706-716. https://doi.org/10.1108/JBIM-07-2017-0166

Gast, J., Kallmuenzer, A., Kraus, S., Gundolf, K., \& Arnold, J. (2017). Coopetition of Small- and Medium-Sized Family Enterprises: Insights from an IT Business Network. International Journal of Entrepreneurship and Small Business, 38, 78-101.

Gębarowski, M., \& Wiażewicz, J. (2014). Contemporary Trade Shows as a Place of Knowledge Sharing about Tourism Products. In Management, Knowledge and Learning International Conference (pp. 335-344). http://ssrn.com/abstract=2706205

Gitonga, P. K. (2016). Customer Relationship Management Practices and Performance of Safaricom Limited in Kenya. Nairobi: University of Nairobi. http://erepository.uonbi.ac.ke/handle/11295/100330

Global Entrepreneurship Monitor (2019). Global Entrepreneurship Monitor 2018/2019 Global Report. London.

Gonçalves, J. M., Ferreira, F. A. F., Ferreira, J. J. M., \& Farinha, L. M. C. (2019). A Multiple Criteria Group Decision-Making Approach for the Assessment of Small and Medium Sized Enterprise Competitiveness. Management Decision, 57, 480-500. https://doi.org/10.1108/MD-02-2018-0203

Government of Malaysia (2016). SME Annual Report 2015/2016. Kuala Lumpur.

Granata, J., Geraudel, M., Gundolf, K., Gast, J., \& Marques, P. (2016). Organisational Innovation and Coopetition between SMEs: A Tertius Strategies Approach. International Journal of Technology Management, 71, 81-99. https://doi.org/10.1504/IJTM.2016.077975

Gray, D., \& Jones, K. F. (2016). Using Organisational Development and Learning Methods to Develop Resilience for Sustainable Futures with SMEs and Micro Businesses: The Case of the Business Alliance. Journal of Small Business and Enterprise Development, 23, 474-494. https://doi.org/10.1108/JSBED-03-2015-0031

Harris, M. A., \& Patten, K. P. (2014). Mobile Device Security Considerations for Smalland Medium-Sized Enterprise Business Mobility. Information Management \& Computer Security, 22, 97-114. https://doi.org/10.1108/IMCS-03-2013-0019

Hassan, S. H., Haniba, N. M. M., \& Ahmad, N. H. (2019). Social Customer Relationship Management (s-CRM) among Small- and Medium-Sized Enterprises (SMEs) in Malaysia. International Journal of Ethics and Systems, 35, 284-302. 
https://doi.org/10.1108/IJOES-11-2017-0192

Healy, B., O’Dwyer, M., \& Ledwith, A. (2018). An Exploration of Product Advantage and Its Antecedents in SMEs. Journal of Small Business and Enterprise Development, 25, 129-146. https://doi.org/10.1108/JSBED-06-2017-0206

International Finance Corporation (2006). A Diagnostic Study on Access to Finance for Women Entrepreneurs.

https://www.ifc.org/wps/wcm/connect/topics_ext_content/ifc_external_corporate_site/sustainabi lity-at-ifc/publications/publications_report_accesstofinance-southafrica_wci_1319578196900

Irungu, A. W., \& Arasa, R. (2017). Factors Influencing Competitiveness of SMEs in Nairobi County, Kenya. International Journal of Entrepreneurship and Project Management, 2, 22-46.

Jain, A., Bhatti, R. S., \& Singh, H. (2015). OEE Enhancement in SMEs through Mobile Maintenance: A TPM Concept. International Journal of Quality \& Reliability Management, 32, 503-516. https://doi.org/10.1108/IJQRM-05-2013-0088

Jardon, C. M. (2018). Location and Competitiveness in Subsistence Small Businesses. Competitiveness Review: An International Business Journal, 28, 155-171. https://doi.org/10.1108/CR-11-2016-0075

Jenkins, B., Akhalkatsi, A., Roberts, B., \& Gardiner, A. (2007). Business Linkages: Lessons, Opportunities and Challenges. Cambridge, MA: IFC and Harvard University.

Jerzyk, E. (2016). Design and Communication of Ecological Content on Sustainable Packaging in Young Consumers' Opinions. Journal of Food Products Marketing, 22, 707-716. https://doi.org/10.1080/10454446.2015.1121435

Kenya National Bureau of Statistics (2016). Micro, Small and Medium Establishments: Basic Report 2016. Nairobi. http://statistics.knbs.or.ke/nada/index.php/catalog/91

Kraus, S., Klimas, P., Gast, J., \& Stephan, T. (2019). Sleeping with Competitors Forms, Antecedents and Outcomes of Coopetition of Small and Medium-Sized Craft Beer Breweries. International Journal of Entrepreneurial Behavior \& Research, 25, 50-66. https://doi.org/10.1108/IJEBR-09-2017-0356

Ledikwe, A., Roberts-Lombard, M., \& Klopper, H. B. (2019). The Perceived Influence of Relationship Quality on Brand Loyalty. African Journal of Economic and Management Studies, 10, 85-101. https://doi.org/10.1108/AJEMS-04-2018-0113

Liu, G., Ko, W. W. J., Ngugi, I., \& Takeda, S. (2017). Proactive Entrepreneurial Behaviour, Market Orientation, and Innovation Outcomes: A Study of Small- and Medium-Sized Manufacturing Firms in the UK. European Journal of Marketing, 51, 1980-2001. https://doi.org/10.1108/EJM-11-2016-0663

Maskell, P. (2014). Accessing Remote Knowledge-The Roles of Trade Fairs, Pipelines, Crowdsourcing and Listening Posts. Journal of Economic Geography, 14, 883-902. https://doi.org/10.1093/jeg/lbu002

Matanda, M. J., \& Ndubisi, N. O. (2009). Market Orientation, Supplier Perceived Value and Business Performance of SMEs in a Sub-Saharan African Nation. Journal of Enterprise Information Management, 22, 384-407. https://doi.org/10.1108/17410390910975013

Measson, N., \& Campbell-Hunt, C. (2015). How SMEs Use Trade Shows to Enter Global Value Chains. Journal of Small Business and Enterprise Development, 22, 99-126. https://doi.org/10.1108/JSBED-09-2011-0025

Meru, A. K., \&, \& Struwig, M. (2015). Business-Incubation Process and Business Development in Kenya: Challenges and Recommendations. Journal of Entrepreneurship and Innovation in Emerging Economies, 1, 1-17. 
https://doi.org/10.1177/2393957514554982

Min, T. S., Idris, M. Z., \& Yusoff, S. O. S. (2018). Exploring Small and Medium Enterprises (SMEs) Food Packaging as a Touch Point to Promote Nation Branding at Kuala Lumpur International Airport (KLIA). International Journal of Academic Research in Business and Social Sciences, 8, 1349-1360. https://doi.org/10.6007/IJARBSS/v8-i10/5303

Mwitari, D. (2018). How Kenyan SMEs Conquered the World of Exports. Standard Newspaper.

Ngugi, D. (2019). Soko Yetu-Twiga Foods. https://twiga.ke/marketplace

Nyamagere, G. S., \&, \& Nchimbi, I. M. (2018). Insights on Impact of Business Development Services on Growth of Women Owned Enterprises in Tanzania. Journal of Management and Strategy, 9, 82-93. https://doi.org/10.5430/jms.v9n1p82

O'Hara, B. S. (1993). Evaluating the Effectiveness of Trade Shows: A Personal Selling Perspective. The Journal of Personal Selling \& Sales Management, 13, 67.

OECD (2018). Leveraging Business Development Services for SME Productivity Growth: International Experience and Implications for United Kingdom Policy. Paris.

Okeyo, W. O., Gathungu, J., \& K’Obonyo, P. K. (2014). The Effect of Business Development Services on Performance of Small and Medium Manufacturing Businesses in Kenya. International Journal of Business and Social Research, 4, 2-16.

Okundaye, K., Fan, S. K., \& Dwyer, R. J. (2019). Impact of Information and Communication Technology in Nigerian Small- to Medium-Sized Enterprises. Journal of Economics, Finance and Administrative Science, 24, 29-46. https://doi.org/10.1108/JEFAS-08-2018-0086

Ombi, N., Ambad, S. N. A., \& Bujang, I. (2018). The Effect of Business Development Services on Small Medium Enterprises (SMEs) Performance. International Journal of Academic Research in Business and Social Sciences, 8, 117-130. https://doi.org/10.6007/IJARBSS/v8-i3/3910

Ongoncho, S., Ngugi, P., Odhiambo, R., \& Kamaara, M. (2017). Relationship between Technical Training and the Performance of Micro and Small Enterprises in Kisii County. International Journal of Scientific and Research Publications, 7, 574-585.

Puthusserry, P. N., Khan, Z., \& Rodgers, P. (2018). International New Ventures Market Expansion through Collaborative Entry Modes-A Study of the Experience of Indian and British ICT Firms. International Marketing Review, 35, 890-913.

https://doi.org/10.1108/IMR-01-2017-0001

Quaye, D., \& Mensah, I. (2018). Marketing Innovation and Sustainable Competitive Advantage of Manufacturing SMEs in Ghana. Management Decision, 57, 1535-1553. https://doi.org/10.1108/MD-08-2017-0784

Rambe, P., \& Mosweunyane, L. (2017). A Poverty-Reduction Oriented Perspective to Small Business Development in South Africa: A Human Capabilities Approach. African Journal of Science, Technology, Innovation and Development, 9, 289-302. https://doi.org/10.1080/20421338.2017.1322749

Shereni, N. C., Mpofu, N., \& Ngwenya, K. (2018). Exhibitors' Perception of the 2017 Sanganai/Hlanganani World Tourism Expo. African Journal of Hospitality, Tourism and Leisure, 7, 1-13. https://www.ajhtl.com/uploads/7/1/6/3/7163688/article_34_vol_7_3_2018.pdf

Smith, E. (2008). Using Secondary Data in Educational and Social Research. New York: McGraw-Hill Education.

The Oxbridge Research Group (2020). The Ultimate Guide to Writing a Dissertation. 
London: Oxbridge Essays.

TradeMark East Africa (2018). One-Stop Border Posts: Enhancing Trade and Regional Integration in East Africa. Nairobi.

https://www.trademarkea.com/stories/one-stop-border-posts-transforming-trade-and-1 ives/

United Nations Secretary General (2014). Entrepreneurship for Development. In SixtyNinth Session of the United Nations Global Assembly TD/B/C.II/29.

https://unctad.org/meetings/en/SessionalDocuments/ciid29_en.pdf

Yanes-Estévez, V., García-Pérez, A. M., \& Oreja-Rodríguez, J. R. (2019). Arcs of Communication and Small- and Medium-Sized Enterprise Performance. Journal of Advances in Management Research, 16, 625-644.

https://doi.org/10.1108/JAMR-09-2018-0079

Yaseen, A., Bryceson, K., \& Mungai, A. N. (2018). Commercialization Behaviour in Production Agriculture: The Overlooked Role of Market Orientation. Journal of Agribusiness in Developing and Emerging Economies, 8, 579-602.

https://doi.org/10.1108/JADEE-07-2017-0072

Zekiri, J., \& Hasani, V. (2015). The Role and Impact of the Packaging Effect on Consumer Buying Behaviour. Ecoforum Journal, 4, 232-240. 